Знаменський В. І., аспірант

Національна академія статистики, обліку та аудиту

м. Київ, Україна

DOI: https://doi.org/10.30525/978-9934-26-068-1-31

\title{
СУЧАСНИЙ ВПЛИВ БЮДЖЕТНО-ПОДАТКОВОЇ ПОЛТТИКИ НА СОЦІАЛЬНО-ЕКОНОМІЧНИЙ РОЗВИТОК ДЕРЖАВИ
}

Основною умовою економічного зростання та політичної стабільності країни $\epsilon$ ефективна податкова політика держави, так як вона $€$ одночасно як основою проведення загальноекономічних реформ, так і засобом забезпечення соціального добробуту населення. Створення оптимальної податкової політики набуває особливої значимості в період корінних змін в економічному житті суспільства.

Так, в більшості країн 3 перехідною економікою руйнування основ соціалістичного господарювання призвело до значного розбалансування бюджетно-податкової політики, а це в свою чергу, пояснюється неможливістю якнайшвидшої адаптації складного податкового механізму до нових економічних та політичних умов. Незважаючи на це, в суспільстві, де вже формувалася економічна система, проблема будівлі врівноваженої податкової системи не втрачає свого значення, так як 3 розвитком суспільства фінансова система потребує змін. Це пояснюється тим, що фінансова система має велике значення в нормальному функціонуванні економіки і соціальної сфери [4].

Якщо вважати бюджетно-податкову політику частиною фінансової політики держави, то можна сказати, що необхідність ефективного розподілу державних коштів за головними напрямками $є$ одним з гострих проблем у сфері перерозподілу залучених державних коштів. Збільшення бюджетної уваги на соціальні програми послаблює інтерес частини населення до збільшення рівня життя, що негативно впливає на загальний рівень виробництва. При цьому зворотній процес, а саме 
встановлення високих податкових ставок також здійснює негативний вплив. Тому необхідно знайти оптимальний середній врівноважений рівень, значне відхилення від якого може спричинити негативний вплив на загальноекономічний i політичний стан держави [5].

При здійсненні бюджетно-податкової політики регулювання, планування та контроль державного бюджету реалізується правовими нормами, визначеними законами та нормативноправовими актами. Обгрунтована 3 економічної точки зору бюджетно-податкова політика має на меті оптимізацію оподаткування та визначення податкового тягаря. Слід зазначити, що податкова політика є широко обговорюваним та найбільш критикованим об'єктом. Оптимальна податкова політика вважається важливим фактором динамічного розвитку національної економіки.

Починаючи з 90-х років минулого століття податкова система України все ще не досягла такого важливого фактору, як стабільність. Мета і завдання податкової політики залежать від конкретних економічних умов. Визначивши мету i задачі, держава розробляє способи їх досягнення. У сучасній світовій практиці широко використовуються зміна податкового тягаря, заміна однієї форми оподаткування іншою, зміна сфери впливу податку, застосування або ліквідація податкових пільг, диференційовані податкові ставки. Вони формуються під впливом деяких факторів, основними з них є економічні та соціальні умови [1].

Зазвичай мета i завдання бюджетно-податкової політики країни визначаються конкретною економічною кон'юнктурою, а основи цієї політики щороку знаходять своє відображення в державному бюджеті.

Розвинені ринкові країни проводять бюджетно-податкову політику з метою досягнення наступних цілей:

- участь держави в економічному регулюванні, направленому до стимулювання або обмеження господарської діяльності;

- забезпечення усіх органів управління фінансовими ресурсами з метою здійснення економічної і соціальної політики; 
- забезпечення політики регулювання доходів держави.

Основною метою бюджетно-податкової політики є забезпечення правових основ утримання податків від платників та всебічна оцінка економічних відносин, що формуються під впливом оподаткування.

Наступною формою здійснення бюджетно-податкової політики є політика економічного розвитку. В цьому випадку держава знижує податковий тягар для підприємців, скорочує, перш за все, соціальні витрати. Мета цієї політики полягає в тому, що інвестиційна активність збільшується. В результаті втілення цієї політики в економіці спостерігається тенденція до стагнації, збільшується загроза економічної кризи. При здійсненні податкової політики використовуються такі податкові інструменти державного регулювання, як податкова ставка, податковий тягар, податкова база i iн. В цей час держава використовує прямі i непрямі податкові інструменти.

Слід зазначити, що в Україні формування ринкової економіки, інтеграція економіки в світову спільноту відбувається в рамках активної податкової політики [2].

Податкова політика, що проводиться в Україні, направлена на розширення податкової бази за рахунок зниження податкових ставок і податкових пільг, стимулювання інвестиційних вкладень, зрівнювання податкового тягаря між фізичними особами та приватними підприємцями, між резидентами і нерезидентами, формування сприятливих умов для бізнесової діяльності дрібних i середніх підприємців, і в кінцевому рахунку на збільшення економічного потенціалу і соціального добробуту населення.

Окремо, серед забезпечення соціального добробуту нашої країни слід відзначити освітню сферу. На жаль, в останні роки вітчизняна освітня система переживає кризу. В умовах недостатнього фінансування кошти, які призначені щоб вдосконалити та оновити умови освіти, спрямовуються у інші сфери, що потребують негайного фінансування [3]. Мова, зокрема йде про боротьбу з пандемією коронавірусу. На цьому слід зупинитися окремо, адже основний вплив на бюджетно-податкову систему в 
сучасних умовах здійснює світова пандемія коронавірусу. Бюджетний процес у 2020 та 2021 роках здійснюється 3 урахуванням впливу пандемії, як у короткостроковому, так і у довгостроковому періодах. Світова криза, пов'язана з пандемією, призвела до значного скорочення економічної активності в усьому світі. Так, реальний ВВП у 2020 році скоротився на 4,8\%. За різними прогнозами аналітиків, у 2021 році цей показник скоротиться ще на 3-8\%. Зараз усі зусилля Міністерства фінансів спрямовані на забезпечення виконання бюджету на 2021 рік, а саме фінансування заходів, спрямованих на боротьбу з пандемією коронавірусу. Державний бюджет на поточний рік передбачає значні статті витрат на медичні потреби (розгортання нових ковідних відділень, закупівля кисневого та іншого обладнання, доплати медичному персоналу, закупівля засобів індивідуального захисту тощо); на допомогу вразливим верствам населення; на підтримку малого та середнього підприємництва.

Функціонування бюджетно-податкової системи як частини фінансової системи є основною умовою економічного розвитку і фінансової стабільності країни, а також засобом забезпечення економічного та соціального добробуту населення.

\section{Література:}

1. Бюджетно-податкова політика у системі регулювання економіки: монографія / І.Я. Чугунов, Т.В. Канєва, М.Д. Пасічний та ін.; за заг. ред. І.Я. Чугунова. Київ. Глобус-Пресс. 2018. 354 с.

2. Інституційна трансформація фінансово-економічної системи України в умовах глобалізації / В.Р. Сіденко, М.І. Скрипниченко, В.С. Пономаренко, І.Я. Чугунов та ін.; за ред. В.Р. Сіденка. Київ: Київ. нац. торг.-екон. ун-т, 2017. $648 \mathrm{c}$.

3. Застрожнікова I.В. Фінансування розвитку освітньої сфери України як механізм їі державного регулювання. Держсавне будівниитво. 2020. № 2.

4. Кучер Г. В. Державні фінансові ресурси: монографія. Київ : Київ. нац. торг.-екон. ун-т. 2018. 600 с.

5. Чугунов І.Я., Брижан К.В. Бюджетна політика в умовах трансформації економіки. Економічний вісник університету. 2017. № 32/1. С. 241-251. 